Revue Française de Civilisation Britannique

XXII-1 | 2017

The Book of Common Prayer : Studies in Religious

Transfer

\title{
Anglican Influence on Old Catholic Liturgy
}

Les Influences anglicanes sur la liturgie vieille-catholique

David R. Holeton and Petr Jan Vinš

\section{OpenEdition}

1 Journals

Electronic version

URL: http://journals.openedition.org/rfcb/1233

DOI: $10.4000 /$ rfcb.1233

ISSN: 2429-4373

Publisher

CRECIB - Centre de recherche et d'études en civilisation britannique

Electronic reference

David R. Holeton and Petr Jan Vinš, "Anglican Influence on Old Catholic Liturgy », Revue Française de Civilisation Britannique [Online], XXII-1 | 2017, Online since 02 May 2017, connection on 21 April 2019.

URL : http://journals.openedition.org/rfcb/1233; DOI : 10.4000/rfcb.1233

This text was automatically generated on 21 April 2019

\section{(c) (i) ()}

Revue française de civilisation britannique est mis à disposition selon les termes de la licence Creative Commons Attribution - Pas d'Utilisation Commerciale - Pas de Modification 4.0 International. 


\title{
Anglican Influence on Old Catholic Liturgy
}

\author{
Les Influences anglicanes sur la liturgie vieille-catholique
}

David R. Holeton and Petr Jan Vinš

1 Whereas borrowing from the Anglican liturgy in the French Reformed Church was an undertaking that had to be very cautiously engaged into not to upset denominational sensibilities, the Old Catholic Churches provide an example of liturgical transfer in which turning to Anglican liturgical resources has been experienced as a way of strengthening old Catholic identity and the communion between the two churches.

2 Anglican influence on Old Catholic liturgy is relatively recent and is the fruit of growing cooperation between the two communions. Mutual relations between the Anglican and old Catholic churches from the 1870s have been of varying intensity and can be divided into several periods. Even before the First Vatican Council a book by J. M. Neale on the history of the Church of Utrecht ${ }^{1}$ brought to the attention of the Anglican public the existence of an independent Catholic church on the European continent. After 1870 and the emergence of the German-speaking Old Catholic churches in reaction to Vatican I, relations with Anglicans went from an optimistic beginning between 1878-1900, through a period of crisis between 1900-1918, of which the most notable incident was the so-called Mathew Affair, ${ }^{2}$ then a period of renewed dialogue, which culminated in the Bonn Agreement of 1931. This important document started a new period of structural cooperation, but its reception by both old Catholics and Anglicans was relatively slow in coming. After the Second World War, liturgical cooperation became visible in mutual participation in episcopal ordinations, but initially there was little sharing in each other's liturgical life. It was thanks to a series of Old Catholic-Anglican theological conferences, starting in 1957, that the two communions created the conditions for sharing their liturgical resources. From the 1980s, as several Old Catholic churches started to revise their liturgies, they made extensive use of contemporary Anglican prayer books, especially from North America. The appeal of these modern Anglican liturgies (compared to the revised liturgies of other Western Churches, which are equally the fruit of the 
Liturgical Movement) lies in the fact that their rootedness in a type of catholicity that is free of Roman theological idiosyncrasies resonates with Old Catholic sensibilities.

\section{Bonn union conferences}

3 The critical Catholic reaction to the First Vatican Council was observed with great interest from the Anglican side; both the Evangelical and the Anglo-Catholic wings saw in the emerging Old Catholic movement a possible ally for their cause. The Evangelicals appreciated the resistance to Rome, the Anglo-Catholic wing on the other hand was interested in a church body living within the Catholic liturgical tradition and promoting an ecclesiastical understanding based on the tradition of the undivided church of the first millennium. In time the Anglo-Catholic connection proved to be stronger and a more viable route down which to pursue liturgical cooperation. ${ }^{3}$ One of the channels of contact between the emerging old Catholic movement and the Anglican Church became the Anglo-Continental Society, founded in 1853 for the promotion of the principles of the Church of England on the European continent, which in 1873 set up its own committee for correspondence with the Old Catholics and arranged for the dissemination of Old Catholic literature in England. ${ }^{4}$

4 In 1873 two Old Catholic Commissions had been established for dialogue with the Anglican and Orthodox churches respectively. The Anglican-Old Catholic commission was headed by Professor Ignaz von Döllinger who in the next two years went even further and organised the so-called Bonn Union Conferences which aimed at a doctrinal-ecclesiastical understanding between Anglican, Old Catholic and Orthodox churches. Those protoecumenical dialogues might be considered the most important inter-confessional meetings of the nineteenth century. ${ }^{5}$

5 The first Bonn Union Conference (1874) accepted fourteen theses, formulated primarily by Döllinger. ${ }^{6}$ One of the questions that remained unsolved - partly because of the opposition of the Orthodox participants and the Church of Utrecht - was the question of the validity of Anglican orders. This proved to be the main obstacle to future Anglicanold Catholic cooperation. Although the German old Catholic church with its newly elected Bishop Joseph Hubert Reinkens was prepared to accept the validity of Anglican Orders, the position of the Church of Utrecht changed only in 1925. The Second Bonn Union Conference was attended by various Anglican Bishops and other delegates from England and the United States. ${ }^{7}$ The topic of the conference was a doctrinal dialogue on the Creed (mainly with the Orthodox), but an important place was also given to the question of the validity of Anglican orders. Döllinger himself vigorously defended the validity of those orders. ${ }^{8}$

The Bonn Union Conferences received a mixed reaction in the Church of England. ${ }^{9}$ It was partly this mixed reaction on the Anglican side - the Evangelicals regarded Old Catholics as being too "catholic" and on the other hand the High Church movement feared that further dialogue with the Old Catholics could negatively influence their attempts to lead a discussion with Rome, a position taken, for example, by Edward Bouverie Pusey - that led to Döllinger's decision not to call a third Union Conference. ${ }^{10}$ 


\section{On the way to the Bonn Agreement}

7 Nevertheless, in 1878 the Second Lambeth Conference expressed its support for the old Catholic movement on the Continent. Two Old Catholic Bishops, Eduard Herzog and Adolf Küry were present at the Lambeth Conference and reported extensively on it in the old Catholic press. The Swiss national old Catholic Synod meeting in 1879 answered the Lambeth declaration with its own affirmation that the old Catholic and Anglican Churches rest on the same foundations. ${ }^{11}$

8 A very interesting liturgical event occurred in 1879, when two old Catholic Bishops Reinkens and Herzog - celebrated the eucharist together along with the Scottish Bishop Cotterill..$^{12}$

9 The Swiss Old Catholic Bishop Eduard Herzog was invited in 1880 to the United States and on several occasions celebrated the eucharist and even confirmed the faithful of the Episcopal Church. This was very warmly received in the Episcopal Church and Bishop Herzog donated a Swiss Old Catholic Altar Book to the House of Bishops of the Episcopal Church. ${ }^{13}$ It seems that at least on one occasion he even ordained a priest for the Episcopal Church who subsequently received permission from his Bishop to use the old Catholic rite. ${ }^{14}$ Bishop Herzog appears to have had a positive disposition towards the American Book of Common Prayer, for it is said that, while preparing the first Swiss Old Catholic liturgical texts (in German), he always had a copy of the American book on his desk..$^{15}$ The fact that, at the time of its creation, the American book had drawn on the liturgy of the Scottish Episcopal Church - with its inclusion of an epiclesis in the eucharistic prayer in particular - gave that book a "catholic/orthodox" character which was missing from the English versions of the Book of Common Prayer.

\section{Formal agreement and living communion}

While between 1870 and 1885 there were many publications concerning Old Catholics on the Anglican side, it seems that the end of the nineteenth century brought a cooling down of relations. The Utrecht Union of the Old Catholic churches was established in 1889 and the position of the Church of Utrecht on the validity of Anglican orders created an ongoing difficulty in the relationship. The consecration of Bishop Kozlowski for the Polish Catholic Church of Chicago in 1897 and the consecration of Arnold Harris Mathew for the non-existent "Old Catholic Church of Great Britain" in 1908 brought mutual relations to an all-time low. Only in 1925 did the situation change when, as a part of the inner renewal of the Dutch Old Catholic Church, they declared "without any reservations that Apostolic Succession was not interrupted in the Church of England." 16 This declaration eliminated the last barrier and the International old Catholic Bishops' Conference expressed its "hope for a future closer fellowship with the Church of England and its affiliated Churches on a truly Catholic foundation. ${ }^{1{ }^{7}}$ " Five years later the Lambeth Conference also affirmed its desire for "a reunification with old Catholics." 18

11 In July 1931 eight members appointed by the Lambeth conference and four representatives of the Union of Utrecht prepared the text of the Bonn Agreement, which was deemed the basis of fellowship at the church level. ${ }^{19}$ The Agreement was ratified by the Old Catholic International Bishops' Conference on September 7, 1931 and by the 
Convocations of Canterbury and York on January 20-21, 1932. This Agreement nevertheless did not include any "instruments of unity" and thus its practical reception was relatively slow on both the Anglican and the Old Catholic sides. Importantly, from the liturgical point of view, the Bonn Agreement explicitly states that it "does not require from either Communion the acceptance of all ... liturgical practice characteristic of the other, but implies that each believes the other to hold all essentials of the Christian Faith." This opened the possibility for mutual critical reception of liturgical texts and practices.

\section{Episcopal contact and theological conferences}

Contacts between German-speaking Old Catholic churches and the Anglican Communion were completely interrupted during the Second World War, but were reinstituted after 1945 and the Bonn Agreement started to be enacted. The most visible form of this enactment was and still is a mutual participation in episcopal ordinations.

This participation in episcopal consecrations constitutes a practical liturgical cooperation between Old Catholic and Anglican churches. Since the 1950s both churches have felt a need not only for practical but also for theoretical and theological consultation. Thus, in 1957 the first Anglican-Old Catholic Theological Conference met as an unofficial body without a formal status, but with a great impact on the practical collaboration of both churches. Subsequent theological conferences dealt mainly with the ecumenical relations of both churches (with the Orthodox, Methodists and Roman Catholics), but some liturgical questions were also raised during these conferences. The seventh theological conference (September 15-18, 1974 in Lucerne) opened the topic of ministry, ordination and the eucharist as well as eucharistic hospitality. The eighth theological conference (April 18-21, 1977 in Chichester) was entirely dedicated to the topic of the theology of ordination. This was the case mainly because the question of the ordination of women had emerged. Through the theological conference individual participants also exchanged their expertise on liturgy and liturgical texts - thus the Old Catholic libraries in Bonn, Bern and Utrecht received new copies of Anglican liturgical books from various parts of the Anglican Communion. The exchange in the other direction was more limited, mainly because Old Catholic liturgical languages (mainly German and Dutch) were inaccessible to most of the Anglican participants. (The Iron Curtain restricted attendance by delegates from Central Europe and rendered Polish and Czech texts unavailable.)

\section{Ongoing reform}

14 The renewal of the liturgy is an ongoing process. Regular pastoral use of the rites prepared by the various Old Catholic and Anglican churches in the 1970s brought an increasing awareness both of the benefits brought to the churches by the reform of the rites as well as an awareness that the work of liturgical reform was far from complete.

Usually there is a lapse of at least a generation between the publication of a Church's new liturgical texts, the reception of those texts and the revision process that follows when work begins on their successors, with the publication of a new prayer book coming, perhaps, half a century later. That was not to be the case with the new generation of 
liturgical texts in the Old Catholic and Anglican traditions and the pace of revisions took on an unprecedented speed.

The momentum begun with the Liturgical Movement and the ensuing, revised liturgical texts emerging from many Churches (most publicly and visibly the Roman Catholic Church) had a profound effect on the life of the western liturgical Churches including both old Catholics and Anglicans.

\section{Common translations}

Many churches began to work together ecumenically. For English speaking churches this began with the work on common translations of liturgical texts shared by many churches. Organizations like the Consultation on Common Texts (CCT) in North America and the Joint Liturgical Group of Great Britain (JLG) first undertook this work and the two groups soon began to work together as ICET (the International Consultation of Liturgical Texts). Eventually ICET came to include equivalent ecumenical groups from Australia (ACOL), New Zealand (JLG-NZ) and South Africa. The Roman Catholic Church was fully included in this work through the participation of ICEL (International Commission on English in the Liturgy). Together they produced translations of a number of standard liturgical texts (including Gloria in Excelsis, the Nicene and Apostles' Creeds, the Lord's Prayer, Sanctus/ Benedictus, Te Deum, Magnificat, Nunc Dimittis \&c.). For English-speaking Christians, this was the first time they had ever shared common vernacular translations of these fundamental texts. ${ }^{20}$

The process of co-operation on common translations also provided an occasion for sharing liturgical books being prepared by the member churches at this time. Out of this emerged what has come to be known as a modern ecumenical liturgical consensus on the shape of the liturgy (particularly the Eucharist).

\section{Sharing new texts}

Given that Old Catholics and Anglicans do not have a common liturgical language, this spirit of practical liturgical cooperation began in a different way - by the mutual exchange of texts. For example, at the beginning of the 1980s, the liturgical commission of the German Old Catholic Church, started a new round of revision. The 1995 altar book of that diocese is the third official book for the celebration of Holy Eucharist, succeeding the rites of 1888 and $1959 .{ }^{21}$

The rite of 1959 was deemed to be rather 'Romanising' as it had reintroduced features of the Roman Mass which had been abandoned in the first altar book in 1888. It became clear to the members of the commission that, if the diocese were to be true to its desire to be as close to the undivided Church as possible, the new German liturgical books of the Roman Catholic Church could not be adopted, even with alterations. The theology of the Eucharist and of the ministry, as well as the pastoral situation of the parishes of the German old Catholic Church were too different from those of the "other" Catholic Church to be suitable for use in the Old Catholic diocese.

21 Furthermore, the advances in liturgical scholarship since the mid-1960s, when the Roman Catholic books had been drafted in Rome, were too significant to be ignored. As the 
revision got under way it was notable that Anglican rites for the celebration of the eucharist were consulted before any other.

This was, in part, due to the fact that Sigisbert Kraft and Joachim Vobbe, the Bishops of the Old Catholics in Germany and themselves liturgists were deeply committed to living out the precepts of the Bonn Agreement. ${ }^{22}$ In the end, it turned out that the single most influential book in this round of revisions was The Book of Alternative Services of the Anglican Church in Canada (BAS). ${ }^{23}$

The BAS proved to be an instant success with the members of the German liturgical commission. The book's catholicity (which did not bow to strictly Roman doctrine or practice), its sensitivity to the extant vernacular balanced by a reverence for the style and rhythm of traditional English liturgical language, and its clarity of structure provided a perfect counter-balance to the Alternative Service Book 1980 of the Church of England which was thought by the commission to be quite inadequate in these areas.

The commission thought that the tradition of liturgical renewal begun by the 1979 Book of Common Prayer of the Episcopal Church (formerly ECUSA) had some mileage and so a number of texts that first appeared in the American 1979 Book of Common Prayer found their way into the German book by way of their inclusion in the BAS.

In working towards new German liturgical texts, Old Catholics also made direct borrowings from the BAS: the first Thanksgiving over the Water (from Holy Baptism, pp. 156-7) and the Litany of Penitence (from Ash Wednesday, pp. 283- 5). The collects used in the BAS proved to be a particularly fruitful source for the creation of the new German texts. Eight Sunday collects were translated and the Canadian texts were always consulted for the other feasts and often served as a basis for their German equivalents.

Additionally, the middle section of the Prefaces (the concrete reason for giving thanks on a particular day) [BAS pp. 218-26] also inspire the German texts. While the prefaces, retain the traditional doxological style at their beginning and end (as opposed to the berakah style used in the BAS), the majority of the twenty-three eucharistic prayers have much in common with the strictly Trinitarian structure as maintained in the BAS: praise of the Father, anamnesis of the mighty acts of God through Christ, including the words of institution (which retain their proper prayer form by saying that Christ "praised your compassion", "gave you thanks and praise", etc.), and an epiclesis of the Holy Spirit over bread and wine and those who eat and drink from the Holy Gifts.

It was not the German Old Catholic Church alone that drew on the liturgical work of the Anglican Communion. Anglican liturgical texts were used as resources when new old Catholic texts were drafted by other Old Catholic churches and by the IALK. The Dutch old Catholic Church, for example, drew on Canadian and English resources when drafting their new eucharistic prayers.

Regular communication between the two communions was significantly improved and formalised when, in 1993, Dr. Thaddeus Schnitker, Secretary of the Old Catholic International Liturgical Commission (IALK), was invited to be an ecumenical member of the International Anglican Liturgical Consultation (IALC). In 1994, Professor David Holeton, then Chair of the IALC was appointed to be the Anglican member of the IALK with the approval of the Anglican Consultative Council. This assured active participation by each communion in the liturgical discussions of the other Church and that each Church would be kept informed of the liturgical activities of the other - particularly work on new liturgical texts. Over time, this has proved to be of considerable importance. 

to be used as a common text in the Union of Utrecht. While the new project is still under way, some Anglican texts have been adapted for rites now in use by particular old Catholic Churches. For example, the rite for the blessing of oils of the Czech Church draws heavily on the BAS. Most notably in both books, the blessing of the oils is incorporated into the Eucharistic prayer itself following early Christian practice in which gifts other than bread and wine were also blessed in the context of the Eucharistic prayer.

As the newest complete sacramentary in the Union of Utrecht, the Czech Missal ${ }^{24}$ contains some important Anglican influences. In part, these are indirect as a number of Eucharistic prayers in the Czech Missal's Rite A are drawn from the new German Altar Book and, thus, incorporate material from the BAS. More directly, the work of the Fifth International Anglican Liturgical Consultation (Dublin, 1995) which was largely devoted to the Eucharist ${ }^{25}$ had a major influence on the new Czech Missal. recommendations of its five working groups. Those of Group III concern the structure of the Eucharist. Reflecting on the experience of these rites in various Anglican provinces over the previous decades, it was clear that various changes were needed to the basic structure of the rite. These included a simplification and reordering of the rite particularly the gathering (or entrance) rite, the treatment of penance within the rite, the placement of the Lord's Prayer and the sign of peace, and the conclusion (dismissal). In outline, the shape recommended by the Consultation for the Sunday eucharist is as follows:

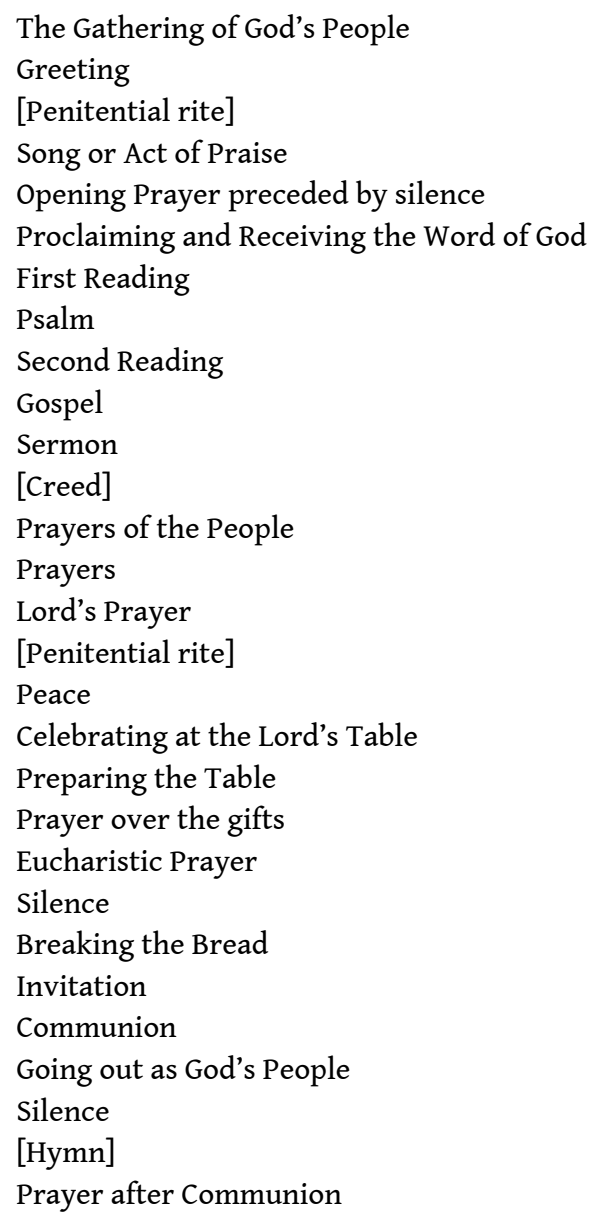


[Blessing]

Dismissal (temport in May 2011 (temporarily) suspended the work of the IALK, thus eliminating an important instrument for Anglican-Old Catholic liturgical cooperation. Until the commission resumes its meetings, common liturgical conversations will rely on less formal contacts between Old Catholic and Anglican members who happen to meet at the biennial congresses of Societas Liturgica or the possible attendance of Old Catholics at meetings of the IALC. Given the important influence of new Anglican Liturgical texts on Old Catholic liturgical renewal in recent years, the importance of these contacts should not be underestimated as various Anglican provinces set about work on a new generation of liturgical texts.

\section{NOTES}

1. John Mason Neale, A History of the So-Called Jansenist Church of Holland (Oxford: John Henry and James Parker, 1858). Old Catholic liturgical texts had been available in English since 1876 with the publication of Frederick Edward Warren's translations in The Offices of the Old Catholic Prayer-Book (Oxford and London: James Parker, 1876).

2. See Christopher Schuler, The Mathew Affair: the Failure to Establish an Old Catholic Church in England in the Context of Anglican Old Catholic Relations Between 1902 and 1925 (Amersfoort: Stichting Oud-Katholiek Seminarie, 1997) for further reference to the Matthew affair and Anglican-Old Catholic relations in the first two decades of the $20^{\text {th }}$ century.

3. Some of the known examples of early Anglican-Old Catholic contact include Bishops E. H. Browne and Christopher Wordsworth's calls for support of the old Catholic movement. The ritualist vicar of St Peter, London Docks, Charles Lowder even attended the Old Catholics' Congress at Constance in 1873; Stewart J. Brown, and Peter B. Nockles, The Oxford Movement: Europe and the Wider World 1830-1930 (Cambridge: Cambridge University Press, 2012), 263.

4. Brown and Nockles, op. cit., 246.

5. Peter Neuner, Döllinger als Theologe der Ökumene (Paderborn: Schöningh, 1979), 178.

6. Heinrich Reusch, ed., Bericht über die 1874 und $1875 \mathrm{zu}$ Bonn gehaltenen Unions-Conferenzen. Neudruckder Ausgabe in zwei Bänden von 1874 und 1875, Schriftenreihe des Altkatholischen Seminars der Universität Bonn, Reihe A,2.

7. The most significant Anglican participants were: Standfort, Bishop of Gibraltar, Dean Howson, Liddon, Plummer, Meyrick (secretary of the Anglo-Continental Society), Malcolm MacColl, 
Plunket (later Archbishop of Dublin), Henry Potter (secretary to the House of Bishops in the USA, later Bishop of New York), Nevin (anglican chaplain in Rome).

8. His speech was recorded by W. S. Perry as such: "I desire, according to an understanding with the gentlemen from the East, to say some words on the question of the validity of the Anglican Orders which has been already spoken of in the former year. The English Church, in the sixteenth century, completed its Reformation without renouncing the Ancient Episcopal Constitution. Under Queen Elizabeth, Parker was consecrated Archbishop of Canterbury, and the historical controversy turns upon the question whether his consecration was valid. Into this controversy, all manner of trifling things have been drawn, and it has, from strange motives, been thrown into confusion. The fact that Parker was consecrated by four validly consecrated Bishops, ritè et legitimè, by laying on of hands and the words which are to be regarded as essential, is confirmed by such ample testimony, that one, if he should doubt these facts, could with the same right doubt one hundred thousand facts; or, as some one, after the appearance of the Life of Jesus by Strauss, has done in derision, could represent the history of the first Napoleon as a myth. The fact is as well attested as can be desired for any fact. Bossuet has acknowledged the validity of Parker's consecration, and no critical historian can dispute it. Ordinations of the Romish Church could be impugned with more show of justice. Besides the re-ordinations of the Tenth Century, the following may, in this view, be recollected. At Florence, a peculiar formula of belief was drawn up in the first instance for the Armenians, with the pretended assent of the Council, which was nevertheless properly at an end. In this so-named Decretum pro Armeniis, the doctrine of the Seven Sacraments is especially developed for the instruction of the Orientals; it is the only detailed statement of the kind before the time of the Trent Council. There is found there in regard to ordination the perfectly astonishing declaration that, the matter of this Sacrament is not the laying on of hands, which is not even mentioned, but the porrectio instrumentorum, the delivery of the chalice and the paten. The form also is inexact, drawn out at great length. The decree was to be forced upon the Orientals. Clement VIII even ordered the Orientals to observe this decree in regard to the Sacraments. And yet the porrectio instrumentorum is purely a ceremony, and, in truth, such a one as first arose after the year 1000, and only in the West. How would it be now if bishops, on the ground of this decree, should have viewed the laying on of hands, which is essential to the validity of ordination, as a mere ceremony, and should have discontinued it. The English theologians \{are\} only right energetically to hold this Decretum pro Armeniis before the Romish theologians in England, who attack the validity of the Anglican ordinations, and remind them that those who live in glass houses should not throw stones."; William Stevens Perry, The Reunion Conference at Bonn 1875, printed privately, 1876.

9. Mark D. Chapman, 'Liddon, Döllinger and the Bonn conferences of 1874 and 1875; A Case Study in Nationalism and Ecumenism', IKZ 92 (2002): 21-59.

10. Angela Berlis, "Relations with the Anglican Church" [online article], retrieved from: http:// www.utrechter-union.org/page/294/relations_with_the_anglican_chur

11. Urs Küry, Die altkatholische Kirche: Ihre Geschichte, ihre Lehre, ihr Anliegen (Stuttgart: Evangelisches Verlagswerk, 1978), 107.

12. Harald Rein, Kirchengemeinschaft: Die anglikanisch-altkatholisch-orthodoxen Beziehungen von 1870 bis 1990 und ihre ökumenische Relevanz (Bern: Peter Lang 1993), 126; in the Old Catholic press the event was reported by Jean-Francois Mayer in Der Katholik 33/1879 (Bern, 1879): 260-262.

13. Harald Rein, op.cit., 129.

14. "Bericht des Bischofs über die Geistlichkeit", Der Katholik 25/1887 (Bern 1887): 197; Harald Rein, Kirchengemeinschaft, 129.

15. The extent of this influence has never been researched. I am grateful for this information to Emeritus Professor Urs von Arx of the Old Catholic Theological Faculty in Bern.

16. Urs Küry, op. cit., 468.

17. Loc. Cit.

Revue Française de Civilisation Britannique, XXII-1 | 2017 
18. Angela Berlis, op. cit.

19. The text of the agreement reads:

1) Each Communion recognizes the catholicity and independence of the other and maintains its own.

2) Each Communion agrees to admit members of the other Communion to participate in the Sacraments.

3) Intercommunion does not require from either Communion the acceptance of all doctrinal opinion, sacramental devotion or liturgical practice characteristic of the other, but implies that each believes the other to hold all essentials of the Christian Faith.

20. David R. Holeton, "Des traductions communes en anglais: un itinéraire anglican et œcuménique”, La Maison-Dieu 272 (Juin, 2013): 153-178.

21. Die Feier der Eucharistie (Altarbuch für die Feier der Liturgie) (Bonn, 1995). An English translation of the book was published in electronic form as The Celebration of the Eucharist in the Catholic Diocese of the Old Catholics in Germany: http://www.alt-katholisch.de/information/liturgie/altarbook. The book has enjoyed widespread influence well beyond its pastoral use within Anglicanism.

22. The episcopates of the two bishops spanned the time from the inception of the project until its completion. Both were enthusiastic supporters of drawing inspiration from the BAS for their own creative work.

23. Thaddeus A. Schnitker, "Eucharist and Catholicity. The influence of The Book of Alternative Services on the New Altar Book of the Old Catholic Church in Germany", Liturgy Canada V.3 (Michaelmas, 1996): 4-6.

24. Eucharistická slavnost starokatolické církve. Český Misál. [The Eucharistic celebration of the Old Catholic Church. The Czech Missal.] (Prague, 2011).

25. David R. Holeton, ed., Our Thanks and Praise. The Eucharist in Anglicanism Today: Papers from the Fifth International Anglican Liturgical Consultation (Toronto: Anglican Book Centre, 1998).

26. Ibid., 259-309.

27. The shape has much in common with the proposed revisions of both the English- and German-language Roman Catholic Sacramentaries - projects which were abandoned after the 2001 publication of the Instruction Liturgiam Authenticam.

28. Český Misál, 36-56.

\section{ABSTRACTS}

Old Catholics have leaned on full communion ties with Anglican churches to create forms of worship which, although decidedly Catholic, are just as decidedly non-Roman, thus strengthening the sense of old Catholic identity. Full communion, established by the Bonn Agreement of 1931, although slow in making an impact on the life of the two denominations, provided a favourable context for extended liturgical consultations from the 1980s, resulting in Old Catholic use of Anglican liturgical resources in drafting new liturgies. The 1995 Altar Book of the Old Catholic Church in Germany, in particular, owes much to the 1985 Canadian Book of Alternative Services, which had itself borrowed heavily from the 1979 revision of the Book of Common Prayer by the Episcopal Church. 
La reconnaissance de la pleine communion entre les Eglises anglicanes et les vieux-catholiques ont permis à ces derniers de créer une liturgie aussi résolument catholique qu'elle est nonromaine, permettant ainsi de renforcer une identité vieille-catholique. Si la pleine communion avec les anglicans, établie par l'Accord de Bonn de 1931, n'a fait sentir ses effets que très lentement dans la vie des deux confessions, elle a offert un cadre favorable à de nombreuses consultations liturgiques depuis les années 1980. Elles ont conduit les vieux-catholiques à utiliser les ressources liturgiques anglicanes pour élaborer leurs nouvelles liturgies. Le Livre d'autel ( Altarbuch) de 1995 de l'Eglise vieille-catholique d'Allemagne, en particulier, est très redevable au Book of Alternative Services canadien de 1985, qui doit lui-même beaucoup à la révision de $1979 \mathrm{du}$ Book of Common Prayer de l'Eglise épiscopale aux Etats-Unis.

\section{INDEX}

Mots-clés: Eglise vieille-catholique, Eglise anglicane, liturgie

Keywords: Old Catholic Church, Anglican Church, liturgy

\section{AUTHORS}

DAVID R. HOLETON

Charles University, Prague

\section{PETR JAN VINŠ}

Charles University, Prague 